\title{
DESIGN AND E-VOTING INFORMATION SYSTEM BASED WEB USING E-KTP ON ELECTION OF THE HEAD OF CITY OF SEMARANG
}

\author{
Rina Dwi Yunita Sari ${ }^{1}$, Sindung H.W.S., BSEE., M.Eng.Sc.. ${ }^{2,}$ Sri Anggraeni \\ K.,S.T., M. Eng. ${ }^{3}$ \\ 1,2,3 Telecommunication Engineering, Politeknik Negeri Semarang \\ rinadwiyunitas@yahoo.com
}

\begin{abstract}
Elections of regional heads is the local election process is based on a majority vote. While voting (voting) is one of the stages of elections. A common problem that occurs in the general election that the election and the collection of voters who still use manual way. In this final project designed an election system by taking these problems. The system designed is a system of e-voting. E-voting system is a method of polling / voting by electronic media and the Internet, making it easier and speed up the selection process. The system can be minimized by using e-KTP and fingerprint identification as data validation as well as a web-based information that is easily accessible to users and the public in obtaining information related to the implementation of e-voting.
\end{abstract}

Index Terms - elections, e-voting, e-KTP, website.

\section{INTRODUCTION}

Developments in information technology and globalization are rapidly influence people to get the job done easily and quickly. All aspects of human life, including democracy and politics as when elections can be conducted using E-Voting System Information. E-Voting Information Systems can be applied at the time of elections (local elections), that still use the electoral system and data collection by using the conventional paper. It has many drawbacks, including the committee should prepare the ballot (ballots), voter data collection is still done by hand, and the process of counting the ballots walk slowly as they need to wait until all ballots collected. So they spend a lot of time,

energy and resources. E-voting system is a method pemugutan / voting by electronic media and the Internet, making it easier and speed up the selection process. With advances in information technology that exist today, a common problem that occurs in the data collection time voters will be voting can be minimized with a system design that can be detected automatically, by using e-ID cards and the use of fingerprint identification as data validation. e-ID card is a document that contains demographic security system / control, whether from the administration or information technology based on national population data bases. E-ID data stored in a database so it is less likely to occur pendouble's voice because a voter can only do once the election (voting). In addition to optimizing the outcome of the elections that are transparent, so it is better if the e-voting system information can be accessed by the entire community.

\section{BASICTHEORY \\ 1.1 E-Voting}

E-voting is a voting process that utilizes electronics. Along with the changing times, there is a shift in meaning related to e-voting. E-voting is now more devoted to the use of information technology, especially the Internet network at the polls.

\subsection{E-KTP}

E-KTP is a document that contains demographic security system / control, whether from the administration or information technology based on national population database. Interface on the chip of e-KTP standards ISO 14443A / B working denganbaik the temperature range between $-25^{\circ} \mathrm{C}$ to $70^{\circ} \mathrm{C}$ and the operating frequency range of 
13.56 MHz. e-ID has a SAM (Secure AccessModule) in the form of 4-7 bytes UID (Unique Identifier).

\subsection{NFC (Near Field Communication) PN532}

NFC (Near Field Communication) is a set of technology-based wireless connectivity technology RFID (Radio frecuency Identity) which uses magnetic field induction to enable communication between electronic devices within a short distance $\pm 4 \mathrm{~cm}$. The most popular NFC module is PN532 NFC capable of communicating wirelessly at a frequency of $13.56 \mathrm{MHz}$.

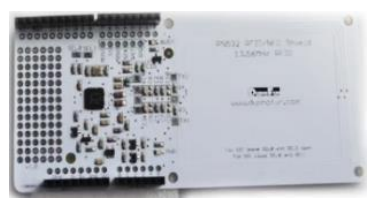

Figure 2.1. Physical form NFC

2.4 Fingerprint sensor module SEN0188 SEN0188 fingerprint sensor module is compatible with the Arduino and has a storage capacity of up to 1000 fingerprints. SEN0188 fingerprint sensor module is a module type fingerprint sensor that uses an optical way. With this technique, a fingerprint pattern is recorded or scanned by using light, fingerprint scanner used was a digital camera.

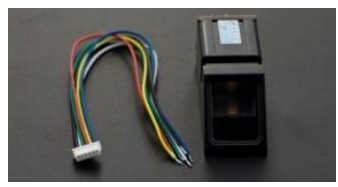

Figure 2.2 Fingerprint module SEN0188

("Fingerprint Sensor," n.d.)

\subsection{Microcontroller Arduino Uno}

Arduino Uno is a microcontroller board based ATmega328P. Arduino Uno Revision 3 (R3) is the last and latest series of USB Arduino series.
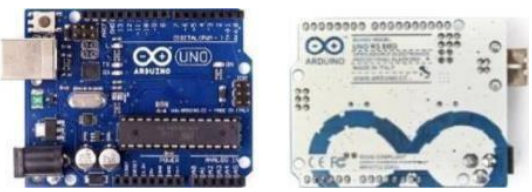

Figure 2.3 Arduino Uno R3 ("Arduino/Genuino

$$
\text { UNO," n.d.) }
$$

\subsection{RFID}

Radio frequency identification (RFID) is a technology that uses communication via electromagnetic waves in order to identify the object.

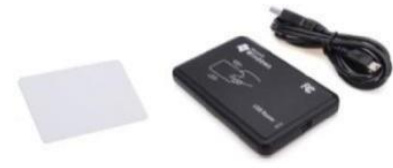

Figure 2.4 RFID Tag and RFID Reader

\subsection{MySQL}

MySQL is a database management system software is free, open source and quite popular existence. Database MySQL relational database form or also called Relation Database Management System (RDBMS) that uses a query language called SQL. MySQL is a program (software) database server while SQL is a programming language used in it.

\subsection{PHP}

PHP (Hypertext Preprocessor) is a web-based programming language written for and by web developers. PHP is open source. In particular, PHP is designed to create dynamic web, which can form a view based on current demand.

\subsection{Visual Basic}

Microsoft Visual Basic (VB) is a programming language that offers Integrated Development Environment (IDE) to create visual-based software program Microsoft Windows operating system by using a programming model (COM).

\section{DESIGN SYSTEM}

\subsection{Representation of Information System E-} Voting

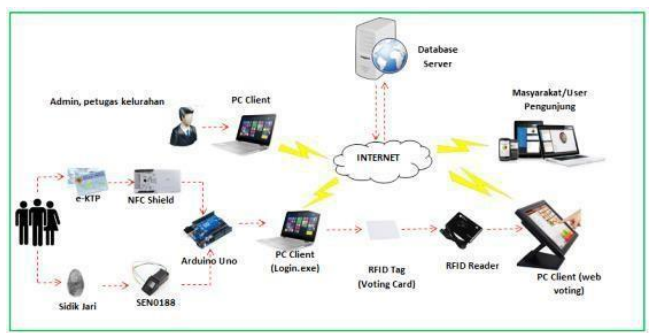

Figure 3.1 Information e-Voting system as a whole

An electronic election system by using internet technology and e-KTP that stores a database of voters.

At the time of election day, voters who were recorded in the database will perform the login process first. Login process is done by identifying the e-KTP and fingerprint. Identification of the eKTP card carried by NFC Shield while fingerprint identification is performed by the fingerprint sensor module SEN0188. Login process performed by the application Form login.exe that will display 
and match data from NFC Shield identification and fingerprint sensor SEN0188, if the login process successfully performed (registered and have not selected), the committee will give a voting card that included a RFID tag, as access to open a

$$
\text { web voting. }
$$

Inside the booth, voting cards will be identified by an RFID reader, if successful it will display web voting and voters are welcome to choose one candidate. Once you have selected, will automatically logout web voting and voting by voters completed. and the results of voting will be entered into the database. Results of voting each tps will be entered into the database through the

Internet.

Once the election is over, the village clerk user can view the data of the election and ordered the system to do recapitulation and. Data from each of each tps voting which has been valid then recapitulated and submitted to the central admin. Results of voting that have been validated by admin center will then be displayed on the e- voting web page that can be viewed directly by the public

\subsection{Hardware Design}

The block diagram of the hardware design of eVoting system information using a web-based e- ID card is shown in Figure 3.2

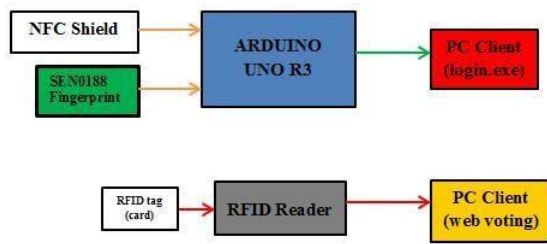

Figure 3.2 Block diagram of the information system e-Voting.

\subsection{Software Design}

\subsubsection{Database Design}

\begin{tabular}{lrrl} 
Name & Engine & Version & Row_format \\
\hline administrator & InnoDB & 10 & Compact \\
artikel & InnoDB & 10 Compact \\
card & InnoDB & 10 Compact \\
hasil_vote & InnoDB & 10 Compact \\
kandidat & InnoDB & 10 Compact \\
kelurahan & InnoDB & 10 Compact \\
pemilih & InnoDB & 10 Compact \\
tps & MYISAM & 10 Dynamic
\end{tabular}

Gambar 3.3 Database of the information system e-Voting.

\section{TESTING AND RESULTS \\ 1.Login Voters}

Voters who have been registered and the status Belum to be able to use their voting rights to login as voters using e-KTP and fingerprint. Access login using Form Login.exe application to display and match UID e-KTP and ID fingerprint database.

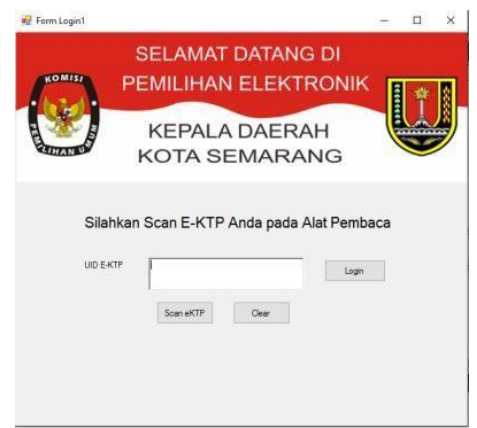

Figure 4.1 The initial view Form Login.exe

After selecting the Scan e-KTP button, then voters are welcome to scan the e-KTP on the reader. Figure 4.2 shows the process of scanning e-KTP is made of voters.

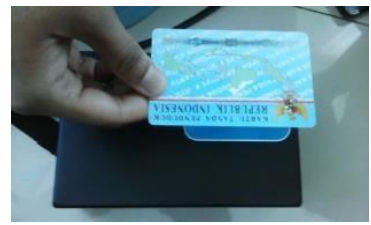

Figure 4.2 Voter scan e-KTP

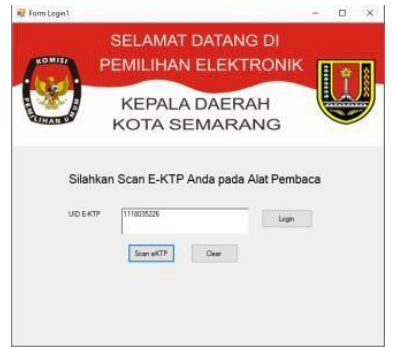

Figure 4.3 Login Form displays UID e-KTP

Officers will select the Login button to check the status of e-KTP voter.

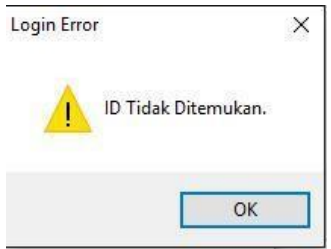

Figure 4.4 Display when UID e-KTP is not registered in the database 


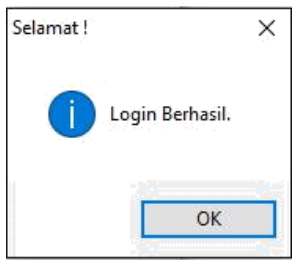

Figure 4.5 Login $e$-KTP success

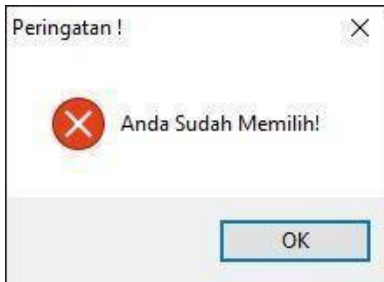

Figure 4.6 Voters are already voting can not choose

If the e-KTP login is successful then the next do the scanning of fingerprints.

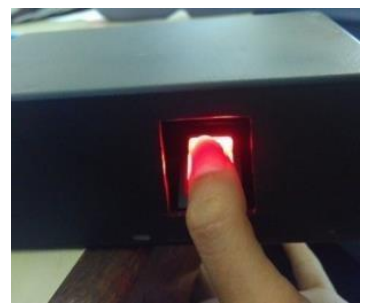

Figure 4.7 Scanning finger

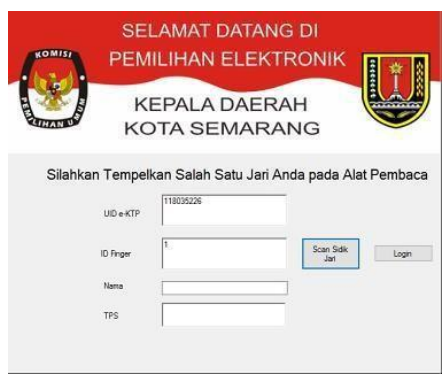

Figure 4.8 Form fingerprint voters to show ID

Figure 4.8 shows the value of ID fingerprint is read, then the clerk will press the Login button to perform UID matching e-KTP and fingerprint.

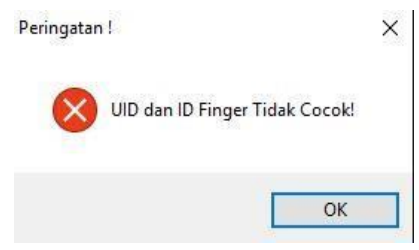

Figure 4.9 UID e-KTP and ID fingerprints do not match

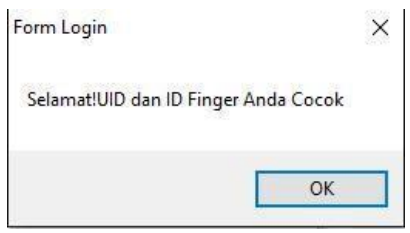

Figure 4.10 Display if the ID and ID Finger match the database

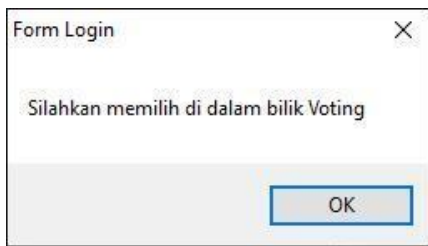

Figure 4.11 Voters are entitled to vote

\section{Voting Proccess}

To do the voting, the clerk will give a voting card as voter access to web voting. Voting card contains an ID tag that will be read by RFID Reader

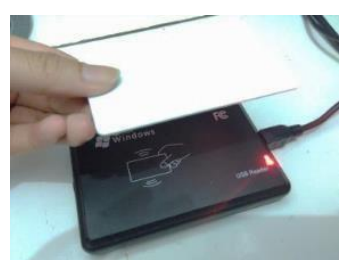

Figure 4.12 Scanning process tag voting card

The tag will then be matched with the data in the database by pressing Login

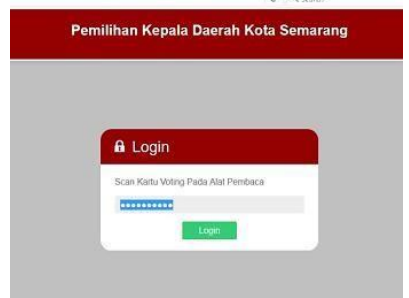

Figure 4.13. Process Login using the Voting Card

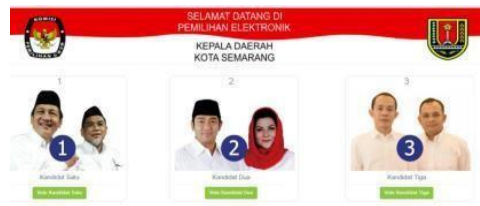

Figure 4.14 Voting Page

3. Record Proccess and Upload Voting Result Once the election is over, the officer can see the results of voting, record data, and upload files record of the voting results by selecting a button or buttons Rekap Data or Upload File Rekap as in the picture 4.14 . 


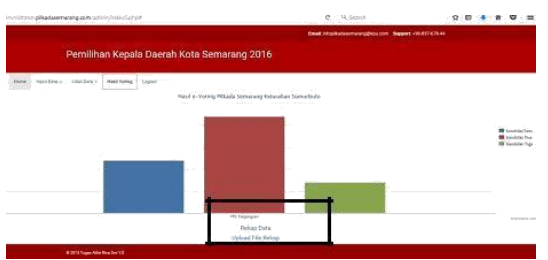

Figure 4.14 Graph of the results of voting on the page administrative officer

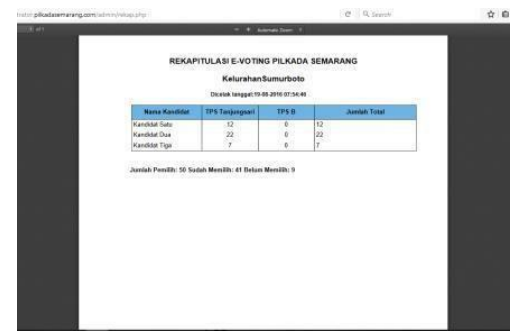

Figure 4.15 The results of the data record administrative officer Sumurboto

Pdf document data that has been downloaded by village officers may be submitted to the admin clerk with the action upload data from the recap. Voting results data that has been uploaded by village officials will enter the account admin officer.

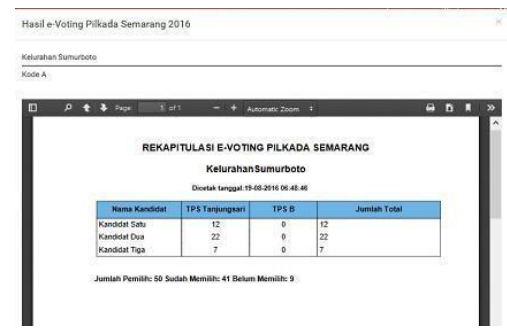

Figure 4.16 Document of the Kelurahan Sumurboto voting results on the admin page

Voting results data can also be viewed by the public to access the information system of e- voting through www.pilkadasemarang.com address.

Voting results can be showed on the menu Voting results in the form of graphs as in Figure 4.17 and the table contains a pdf document as in the picture 4.18.

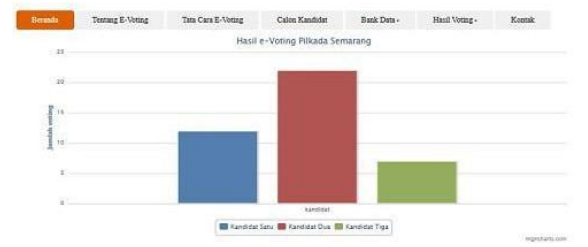

Figure 4.17 Graph of the results of voting on the user page visitors

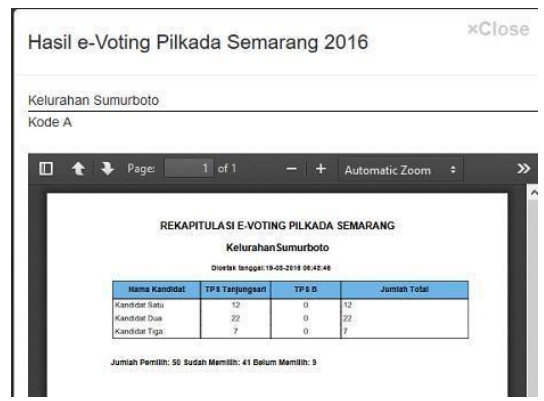

Figure 4.18. Table documents the results of voting on the user page visitors

\section{CONCLUSION}

Based on the test results of the final project "Construction of E-Voting System Information Using Web-Based E-KTP", then it can be taken several conclusions as follows:

1. Systems has been meeting the needs of the community to make the election of Regional Head by utilizing technology and the Internet..

2. People can find out information about evoting, includes data polling stations, voters' data, and to know the voting results in a timely and transparent.

3. The system information provided can be used by administrators to manage data polling, candidate data, the data of voters and voting merekap and displays the results in a timely and transparent.

4. Information E-Voting System Using Web-Based E-KTP card can only work within the system online so that when there is no internet connection then the system can not run.

\section{BIBILIOGRAPHY}

[1]. “Apa dan Mengapa e-KTP” 2011. http://www.e-ktp.com/2011/06/helloworld/. (August 8, 2016).

[2]. "Arduino/Genuino UNO." https://www.arduino.cc/en/Main/ArduinoBoa rdUno (August 12, 2016).

[3]. "Fingerprint Sensor." http://www.dfrobot.com/index.php?route=pro duct/product\&product_id=1343\&search $=$ FIN GERPRINT\&description=true\#.V8TrVbPO WSo. (August 15, 2016). 
[4]. "NFC Forum Specification Architecture." http://nfc-forum.org/our- work/specificationsand-application- documents/specifications/

(August 15, 2016).

[5]. "NFC Shield”. 2015.

http://www.seeedstudio.com/wiki/NFC_Shi eld V2.0.( August 8, 2016).

[6]. Bintaro, Surya. 2012. Tip \& Trik Membuat Program Penjualan Menggunakan Visual Basic 6.0. Jakarta Selatan: Media Kita

[7]. Nugroho, Bunafit.2005. Database Relasional dengan MySQL. Yogyakarta: ANDI

[8]. Shalahuddin, Muhammad.2009. Pembuatan Model E-Voting Berbasis Web (Studi Kasus Pemilu Legislatif Dan Presiden Indonesia). Tesis. Bandung: Program Magister Inforamatika ITB.

[9]. Solichin, Achmad. 2016. Pemrograman web dengan PHP dan MySQL. Budi Luhur.

[10]. Yulius, 2014. "Radio Frequency Identification (RFID).” http://sis.binus.ac.id/2014/04/12/radiofrequency-identification-rfid/ (August 9, 2016). 